\title{
JLA FORUM
}

\section{Riding Along with Police: Opportunity for Learning and Beyond}

\author{
ANITA M. WATERS
}

\section{Introduction}

In the summer of 2008 I sent out a call to thirty former students from three semesters between 2000 and 2005, to reflect on what they learned from the "ride-alongs" with police, whether the project has changed their views on social order and the state, on the practice of law enforcement, and on the process of gathering knowledge about social life in general. Ten responded, and their ideas show that the experience of police ethnography had a considerable impact.

Of the students who replied, a remarkable number have a personal connection to the law in their current lives; this probably motivated them to take the time to answer my inquiry. Two had parents in law enforcement, two have significant others who are officers, two others are lawyers, and one, I was surprised to learn, is currently attending a police academy. Their reports generally indicated a shift toward a more positive view of law enforcement than they held previously. The most extreme shift was expressed by Ashley Fuller who is currently training to become a police officer. She started out the ride-along with a distinctly negative perspective on police, a result of exposure to the certain major incidents. She pinpointed:

Rodney King beatings, racial profiling and recently the Sean Bell killing which portray police officers in a negative way. From those incidents I concluded that police officers were violent, racist and corrupt beings of society. However, the ride-along gave me a different perspective of police officers. I was able to see a humane side of police officers. I had to realize that not every officer is racist or corrupt and that the media sensationalizes the facts to create an image that may be unfair to officers. 
Through her ethnographic work, Ashley changed from someone who was critical of the police to someone who could understand their point of view to the extent that she wanted to become one of them. Ashley reports that the pride one of the officers expressed both about helping others and about being from a family of police officers "was a feeling that I wanted to feel." She will graduate from the police academy later this year.

\section{Empathy and power}

Other students on "ride alongs" also found that their fieldwork with the police provided spaces for humanizing these law enforcement agents. At the same time, some noted that they were also more aware of the way officers were likely to misuse power. Nimo Singh, for instance, noted that she gained better understanding of the police after conducting her fieldwork and she lauded their goals. However, this did not change her views that their discretionary power was troubling. She noted:

Part of me feels more sympathetic for police officers; however, there have been incidents where I feel that police officers have used their power in a negative way. For example, one of the officers I rode with told me that sometimes they just pull people over because they are bored or if they are having a bad day. It's just kind of scary that someone who may be "bored" or has a "bad day" has the power to pull you over and give you a ticket just because he or she feels like it.

Alicia Hurle wrote about her Green Park village officer who was young and "seemed very immature," becoming very excited about a possible car chase. She continues:

My ride-along with him really broke down the façade of power and authority that police officers seemed to have in society. Initially I thought that that would lessen my fear of police, but then I realized understanding that police were just like anyone else made the amount of power they had even more frightening. Now their use of authority seems much more arbitrary and unpredictable to me because I see them as everyday people.

Scholars often note that law enforcement is one of the few endeavors in which paradoxically, the lower echelons have a greater amount of discretion. While higher ranking police officials act within restrictive constraints and are more often in the public eye, rank and file cops choose whom to investigate and arrest. Jonathan Curran recognized that the leeway officers enjoy influences the way society draws the boundary between good citizens and deviants: 
I remember that one officer commented that it was very easy to find "stupid reasons" to pull drivers over, and that they could effectively stop anyone they wanted; conversely, they also have the option of not pulling people over for those same minor violations. Because of this, there is a bit of flexibility in practice as to where the dividing line between deviant and non-deviant behavior falls, although the law itself is usually quite specific.

The field study includes contrasting police jurisdictions which allows students to gain a heightened sense of the way the economic status of a community shapes police officers' working lives. Policing a small, wealthy village often means checking that vacationing residents' doors are still locked and issuing speeding tickets to drivers from out of town. The Green Park police were sometimes viewed as "glorified parking meter attendants" who "harass college students and give out speeding tickets." Lisa Wright Baer reported that on her ride-alongs, the officer there seemed "a little desperate" to find something to do, even following cars that seemed to hold a hope for future violations. She noted his disappointment that he could only find compliance with the law everywhere he looked. In an added irony, despite the low demand on their services, Green Park officers conduct their business with the latest high-tech equipment thanks to the wealth of the village.

In contrast, officers for the Lancaster County Sheriff's Department and Newmarket Police Departments offered students more memorable experiences that gave them a sense of the stress and hazards of police work. Newmarket officers were often called to situations of domestic abuse and neighborhood disputes, expected to be "intermediaries, peace-keepers and even therapists," in Katie Johnson's words, and were much less expensivelyequipped than Green Park police. Policing the vast geography of Lancaster County means venturing into hazardous situations like drug labs in the isolation of the country-side, where cell phones don't work and back-up assistance might be a half-hour's drive away.

\section{Students and the police}

Police ride-alongs offer a complex venue for observing both an occupational role and the social worlds with which it interacts. According to David Bayley, riding along with police allows students to "see first hand the way freedom and order are balanced or distributed ... Cops take you anywhere, and you have a license to watch" (Bayley 2000). Jonathan van Balen pointed out the importance of mobility to the kinds of information that a ride-along yields:

Location was significant for each officer, because when we would pass a certain spot, it would remind them of a story or a situation, which would lead to a conversation about something different about their 
job or their background. I also got to see more of the area surrounding the campus in three days than I had in the three years I had been there.

Pedagogical goals aside, I would argue that conducting field research on policing has other important social consequences. Although we assure the police of confidentiality and promise not to publish exposés of our findings, riding along with police and engaging them in conversation is one of few opportunities for systematic observation of police activities by members of the public. These opportunities are shrinking quickly. Michael Jacobson, director of the Vera Institute, reported that security and liability issues as well as "a political sense that nothing good can come of it" has drastically reduced access to prison populations that scholars used to have (Glenn 2008). Richard Erikson has demonstrated that police agencies "expend considerable resources in patrolling the facts of their operations (...) They strategically organize physical facilities, cultural sensibilities and social relations to construct silence about most of their activities" (1989:224). The tensions inherent in the relationship between police agencies and the general public push bureaucracies toward greater secrecy and simultaneously make transparency about police behavior even more valuable to democratic societies. Cadres of student ethnographers make at least a modest contribution toward that end.

My "Field Research Methods" course in a merged sociology/anthropology undergraduate program culminates in a the class project in which students observe police officers and sheriff's deputies as they go about their ordinary working lives. As demonstrated above, students make contacts, establish rapport, interview, take notes and write comprehensive field notes, analyze qualitative data, make use of field notes written by other observers, and write analytic reports. Each student rides along with officers from each of three departments located near the campus of our small, liberal arts college in Ohio. One department serves the needs of an affluent village we call "Green Park," with just over 3000 people and a mean household income of nearly $\$ 70,000$. The second, "Newmarket," polices an adjacent city of 46,000 with a significant working class population; mean household income is less than half that of the village. The last is a "Lancaster County" agency run by an elected sheriff that handles a vast rural expanse of nearly 700 square miles, with a population of 145,000 .

The project's primary pedagogical goal is to provide an opportunity for students to conduct independent fieldwork. Practical experience gives students the best sense of the richness of insight and the range of observations that can only be gained in the field. They also get a taste of the challenges of field studies, from taking notes in a dark speeding car to maintaining a professional demeanor in situations fraught with uncertainty.

Before entering the field, students take a glimpse at the rich literature of police ethnographies, beginning with Albert Reiss's systematic measurements of police-civilian encounters (1971). We explore the police as a gendered 
occupation (Horn 1997, Martin 1999), the ways police construct meanings that help them make sense of their public lives (Herbert 1996, Leo 1996), how other constituencies perceive the political role of the police (Sunshine and Tyler 2003, Sklansky 2008), the ways that police manage their own and others' emotions (Steinberg and Figart 1999, Smith and Waters 2001), trends in policing (Bayley and Shearing 1996), the role police play in maintaining structures of inequality (Ross 1998, Ericson 1989), the special characteristics that separate rural police from their urban counterparts (Weisheit and Falcone 1995) and the contrasts between police in the United States and in Japan (Bayley 1991). By looking at police ethnographies over the years, students can see their own place in a venerable research tradition that continues to produce relevant findings.

"To understand the working lives of police from their own point of view" - we reiterate this exact phrase at every opportunity so students' answers to officers' questions are uniform - is our research goal in this project. We want to work toward an understanding of the ways that the police officers themselves make sense of the work that they do. What meanings do they attach to the behaviors of others? How do they conceive of the communities in which they are serving? This overarching goal is broad enough to accommodate a variety of kinds of observations, but specific enough to focus students' attention to the meanings, symbols and attitudes of police culture, and substantial enough to make connections to interpretive theories in sociology and anthropology. Students who need more structure for their note taking were instructed to observe social interactions between police officers and various "others." These interactions are seen as key to understanding the working world from the participants' viewpoint. The "others" include: superiors in the police hierarchy, dispatchers, other police officers, members of the public, potential perpetrators or suspicious persons, victims of crime, bystanders, and so forth. If the police officer was not interacting with others (these were one-officer patrol cars), the student observer could conduct an informal interview with the officer about his or her interactions with various members of the community.

Before entering the field, students discussed the effects that status characteristics, including race/ethnicity, gender, age and social class, might have on the research process. Differences in statuses between the students and the officers might trigger stereotypical responses on both sides. All of the officers my students have ridden with have been of Anglo-European descent (i.e. white, non-Hispanic) and almost all are men; two of the three departments have one woman each on the force and the third has none. Their occupation places them solidly in the middle class and most were born and raised in this same geographic area. My students, in contrast, come from places like California and India as well as Ohio, and include AfricanAmericans and Latino/as; a majority are women. They come from diverse economic backgrounds from working class through upper class, and they 
attend a private college that is perceived as privileged and distant, especially in the adjacent working class town of Newmarket.

Students are instructed to keep a notebook with them at all times and jot down notes throughout the time that they spent with the police officers. Back at their rooms after each field experience, they write up detailed field notes. After spending a minimum of six hours in the field, students post field notes to a course website. Then, using their own and their fellow students' field notes, each student writes an analytic field report based on one or more themes that resonate with the literature that we reviewed before the field experience. Students are asked specifically to "locate themselves in the process" of the field study; they need to reflect on the way their own statuses affected the behavior of others as well as the way student researchers interpreted what they observed. Over the five semesters since 2000 that I have guided students through this process, I have read some superb analyses of the way police officers use humor on the job, interact with children, hold distain for the communities they serve, define their jobs as gendered, haze new recruits, and handle domestic violence, among many other topics.

In short, the police ride-along assignment offers students a valuable opportunity to practice ethnographic skills, to peer behind the façade of governmental pronouncements, and to see their own communities in a brand new light.

\section{Acknowledgements}

I want to thank the following alumni for still completing homework assignments several years after graduation: Alicia Hurle, Kate Corbett, Nimo Singh, Jonathan van Balen, Lisa Wright Baer, Stephanie Hoover, Lindsay Robin, Ashley Fuller, Katie Johnson and Jonathan Curran.

\section{References}

Bayley, David H. (1991) Forces of Order: Policing Modern Japan.

Berkeley: University of California Press.

Bayley, David H. and Clifford D. Shearing (1996) "The

Future of Policing." Law \& Society Review 30 (3), 585-606.

Ericson, Richard V. (1989). "Patrolling the Facts: Secrecy and

Publicity in Police Work." British Journal of Sociology 40 (2), 205-226.

Glenn, David (2008) "Security and Paperwork Keep Prison

Researchers on the Outside." Chronicle of Higher Education. March 28.

Accessed on-line a www.chronicle.com.

Herbert, Steve (1996) "Morality in Law Enforcement: Chasing

'Bad Guys' with the Los Angeles Police Department." Law \& Society Review 30 (4), 799-818.

Horn, Rebecca (1997) "Not 'One of the Boys': Women

Researching the Police." Journal of Gender Studies 6 (3), 297-307.

Leo, Richard A. (1996) "Miranda's Revenge: Police Interrogation as a Confidence Game." Law \& Society Review 30 (2), 259-288. 
Martin, Susan Ehrlich (1999) "Police Force or Police Service?

Gender and Emotional Labor." Annals of the American Academy of Political and Social Science. 561 (January), 111-126.

Reis, Albert (1971) The Police and the Public. New Haven: Yale University Press.

Ross, Jeffrey Ian, editor (1998) Cutting the Edge: Current Perspectives in Radical/Critical Criminology and Criminal Justice. Westport, CT: Praeger.

Sklansky, David Alan (2008) Democracy and the Police. Stanford:

Stanford University Press.

Smith, Leah J. and Anita M. Waters 2001 "Managed Hearts under Bullet-Proof Vests: Teaching Social Process Through Police RideAlongs." Presentation at the American Sociological Association Meetings. Anaheim, California.

Steinberg, Ronnie J. and Deborah M. Figart (1999) "Emotional Demands at Work: A Job Content Analysis." Annals AAPSS 561 (January), 177-191.

Sunshine, Jason, and Tom Tyler (2003) "Moral Solidarity, Identification with the Community and the Importance of Procedural Justice: The Police as Prototypical Representatives of a Group's Moral Values." Social Psychology Quarterly 66 (2), 153-165.

Weisheit, Ralph A., L. Edward Wells and David N. Falcone (1995) "Crime and Policing in Rural and Small-Town America: An Overview of the Issues." National Institute of Justice. http://www.ncjrs.gov/ txtfiles/crimepol.txt.

\section{Recognizing Variation through Police Observation: Using Ethnography to Investigate Police Governance}

\section{CHRIS GIACOMANTONIO}

\section{Introduction}

Anita Waters discusses the importance of police ethnography in forging and re-negotiating students' views of police officers and police work. She rightly argues that police ethnography is both an important and endangered tradition that sets policing activities into a localized context. In my research as a student of policing, I have come to agree with Waters that ethnographic methodologies have been used extensively and effectively in investigating many aspects of policing. However, these techniques have been underutilized 
in analyzing the local idiosyncrasies of police governance, and this aspect of the study is becoming increasingly important to understanding front-line police work.

In this piece, I discuss the importance of ethnography in understanding the particulars of the local as opposed to the universal and general in observing and reporting on police culture and police work. Many largely sociological field studies of the police have had a tendency to presume that what is being observed and studied locally is somehow typical of all police. Missing from these studies has been a more nuanced and specifically contextualized observation approach that is sensitive to the changing nature of the organizational and managerial policy contexts within which police operate.

The ascendance of a number of police governance trends has increased the differentiation between and even within police districts in the way policing is approached and delivered. Using an example from my current research in Halifax, NS, Canada, I illustrate how the local policing structure can encourage variability in policing practices and patterns within a single district. In turn, I suggest that adequate interpretation of my field experience requires an understanding of police practice as situated within local policy, and, conversely, that the effects of that policy are best understood through field observations.

\section{The case for variation}

Classic and contemporary police ethnographies have often looked to explain the formation of police practices and behaviours as a reflection of a broader police culture. Perhaps this reflects a stability in police cultures and structures across districts, and certainly many scholars have indicated as much (see, for instance, Goldstein 1987, Skolnick \& Bayley 1986, Zhao et al 1998). Similar demographics and attitudes are shared by officers in many areas of the 'Western' world. These similarities have often increased the generalizablility of the results of ethnographic police research, which is nice, especially given the increasing difficulty of gaining access to police in the field, as noted by Waters (this volume).

Waters also notes that local economic conditions will affect an ethnographer's observations of police work. Recognizing this truism, classic ethnographies have often been very good about outlining the local socioeconomic or political histories of their field site (see, for instance, Pike 1981, van Maanen 1972, Ericson 1982). However, they often brush past or make broad generalizations in describing the local policing policy model. This assumption of general uniformity in policing models from district to district may be a holdover from the 'professionalization' or 'bureaucratic' eras of policing, which intended to standardize and make uniform police behaviour and practice (Zhao 1996). However, a number of trends in policing may be increasing the differences in practices between and even within policing districts, thus limiting 'broad' conceptions of what it is to be a police officer or to be engaged in policing. 
Nodal or post-regulatory governance (Crawford 2006), neo-liberal reforms and rationalization (Murphy 2004), and probably most importantly, the widespread rise of community-oriented policing (COP) models (Huey 2007, Zhao 1996) have contributed to the presence of at least four distinct policing models in the North American context (Oliver 2006). These include 'traditional' or reactive models, 'community' or democratic models, 'problemoriented' or proactive models, and 'zero-tolerance' or 'broken-windows' models.

Given these changes in the governance of policing, police ethnographers need to start contextualizing the specific environment in which their observations of policing occur in a much more localized way, if they are to flesh out the local idiosyncrasies that will arise from this new governance. Doing so will allow them to avoid crude generalizations while maintaining communication and interpretability between ethnographic works. Huey's (2007) Negotiating Demands is a good example of ethnographic scholarship headed in this direction, as she compares three skid row districts across Canada, the US, and UK, and finds that the differences between districts are predicated largely by their local political-economic and civic constraints. The importance of this approach has been apparent in my thesis research as well, as I take the argument a step further, suggesting that local policy factors may influence differences within districts as well.

\section{An example from Halifax}

Having recently undertaken an ethnographic study of police in Halifax, NS, I have found that separate models of policing may exist in very close geographical proximity to one another, even under the same administrative regime. This policing outcome is enabled in part by the local policing framework, the Halifax Regional Police Service's Community Response Model, implemented in 2006. ${ }^{1}$ This document created a specific position to lead patrol policing activities in certain population-dense areas of the city; this new position, known as the Community Response Officer (CRO), is the central focus of my study.

The CROs demonstrated through observations and interviews that most of their actions are not required to be reported in any significant way, and that they are virtually unsupervised most of the time. Their ability to exercise significant discretion allows their personal beliefs, standards, and initiatives to steer the policing approach in their particular area, as other beat officers in the area look to them for leadership and direction. The role of the CRO produces a variegated kind of policing product, which I have examined through the following comparison of two policing areas, Downtown and Uptown.

Halifax's Downtown police patrol area houses the bulk of the Halifax Regional Municipality's (HRM) homeless population, and is also Halifax's 
central business district. Until recently, the downtown had the highest incidence of violent crime in all of the HRM territory, but it also remains the major entertainment destination for most Haligonians from diverse socioeconomic, age, race, and gender backgrounds. The policing style in Downtown can be characterized as 'zero-tolerance' policing, and I observed beat officers regularly enforcing minor public order offences under direction from the CRO, through ticketing or warning for helmet violations, smoking in prohibited areas, and blocking the sidewalk. I further found that police Downtown rarely interact with residents' groups, and they encourage coproductive security measures for businesses such as target-hardening and maintaining records on local homeless persons. Patrol officers Downtown admitted that they consider it a success if they displace criminal activity from their patrol area to elsewhere in the HRM, and during my observations we regularly moved people 'along', although to no specific place.

Directly adjacent to Downtown is the district known as the Uptown patrol area, which is a poor primarily residential area. This area includes public housing projects, a number of addiction-treatment centres, social and housing services offices, and a small commercial section. Downtown and Uptown are separated by a single street, and both exhibit skid row characteristics. However, the policing of the derelict populations of each which are made up of overlapping populations, to be sure ${ }^{2}$ - changes significantly over a small geographic distance.

While walking along with officers Uptown, I observed virtually zero enforcement of helmet or smoking by-law infractions. Official sanction in the form of ticket or arrest was used rarely, and avoided when possible. The policing style in Uptown would properly be referred to as 'community' policing, and it is far more lenient on low-level criminal violations than the Downtown approach. Police Uptown regularly interact with residents' groups and social service providers, and co-produce neighbourhood projects such as a community garden and help to distribute charity goods such as furniture, food and housewares. Co-productive security measures encouraged by Uptown officers include meetings with at-risk youths and their parents in partnerships with other local programs. As well, contrasting the Downtown displacementas-success ethos, Uptown officers were seen to take ownership of criminal activity from 'their' locals, even when the actual crimes take place outside of Uptown. ${ }^{3}$

Halifax's Community Response Model facilitates this localized variability in observed policing practices. Upon reviewing the policy model on its own, one may be led to believe that policing is relatively uniform throughout the municipality - each policing zone has its own Community Response Officer, all CROs answer to a staff sergeant, and they all share a common mandate. However, by using participant observation to situate the behaviours of officers in a highly local context, we can see that policing styles, mandates, selection of patrol personnel, arrest patterns, and patrol patterns may all differ on an almost block-to-block basis, independent of levels of criminal incidents. 
Recognizing this variation problematizes our ability to properly situate Halifax as either a community model or a zero-tolerance model, as aspects of both approaches to policing are apparent in the city. We might be inclined to conclude that we have found a new policing model that does not fit in the typology described by Oliver, if we equate a single police force with a single policing model. An awareness of the local policy context, however, suggests that we are actually observing two well-known policing models working sideby-side in a coherent fashion under the same administrative structure, and that they do not overlap. That the policing model may change as one crosses a single street can therefore be understood in this way only if one recognizes the particulars of the local policing policy structure, and the actual effects of this structure can only be understood through observation.

\section{Conclusion}

Waters is right to emphasize the importance of ethnography in shaping students' and researchers' views on police and policing. However, recent changes in policing have challenged the generalizability of police ethnographers' findings in significant ways. As illustrated by my current research in Halifax, as we move from the era of bureaucratic and centralized policing models to COP models that are responsive to local needs, we will experience increasing differentiation of practices between and even within police forces.

In turn, this differentiation presents specific challenges to police ethnographers. As policing becomes increasingly decentralized, more attention must be paid to the specific and idiosyncratic effects of local policy on police actions, and the effects of policy can best be investigated through a localized observational approach. Recognizing these principles will allow police ethnographies to recognize and adequately report on the variations inherent in the actual application of emerging police governance trends.

\section{Acknowledgement}

I thank Chris Murphy at Dalhousie University for his comments and advice on this article.

\section{Notes}

1. These findings are based on current research. This model stresses 'generalist' policing for beat officers and increased officer discretion based on local demands. Further, it places the Service's 'community' policing functions primarily in three particular units - Community Response Officers (CROs), the Quick Response Unit (QRU), and foot patrol officers while the rest of the force retains many of the traditional reactive policing responsibilities.

2. One officer made an interesting comment to me during a walk-along, that the Downtown - which offers panhandling opportunities - is where the local homeless go to 'work', while 
Uptown, which has more available social services and street drugs, is where they go to 'live'.

3. This is not to say, exactly, that they feel responsible for the criminal offence. Rather, they will take the time to get to know, and where possible provide assistance to, the offenders in their area, especially where the offender is young or at risk for worse activity in the future, and regardless of where the criminal activity takes place.

\section{References}

Crawford, Adam (2006) Networked governance and the post-regulatory state?

Steering, rowing and anchoring of policing and security. Theoretical Criminology 10(4): 449-479.

Ericson, Richard V. (1982) Reproducing Order: A study of police patrol work. Toronto: University of Toronto Press.

Goldstein, Herman (1987) Toward Community-Oriented Policing: Potential,

Basic Requirements, and Threshold Questions, in Alpert, Geoffrey P. and Alex Piquero (eds) Community Policing: Contemporary Readings, pp. 322. Illinois: Waveland Press

Huey, Laura (2007) Negotiating Demands: The politics of skid row policing in Edinburgh, San Francisco and Vancouver. Toronto: University of Toronto Press.

Murphy, Chris (2004) The Rationalization of Canadian Public Policing.

Canadian Review of Policing Research 1.

Oliver, Willard M. (2006) The Fourth Era of Policing: Homeland Security. International Review of Law Computers 20(1\&2): 49-62.

Pike, Diane (1981) Making Rookies: The Social Organization of Police Academy Training. Yale University PhD Dissertation.

Skolnick, Jerome H. and David H. Bayley (1986) The New Blue Line, in Carl B. Klockars, and Stephen D. Mastrofski (eds) Thinking about Police: Contemporary Readings $2^{\text {nd }}$ Edition. USA: McGraw Hill.

Van Maanen, John (1972) "Pledging the Police." PhD dissertation, University of California: Berkeley.

Zhao, Jihong (1996) Why Police Organizations Change: A study of communityoriented policing. Washington: Police Executive Research Forum.

Zhao, Jihong et al (1998) Community-Oriented Policing Across the US:

Facilitators and Impediment to Implementation, in Alpert, Geoffrey P. and Alex Piquero (eds) Community Policing: Contemporary Readings, pp. 413426. Illinois: Waveland Press.

\section{Chris Giacomantonio}

Department of Sociology and Social Anthropology

Dalhousie University, Halifax, NS, Canada B3H 4 PO

ch451698@dal.ca 


\section{Overcoming Resistance, Observing State Power: On the Multiple Benefits of Police Ethnography}

\section{STEVE HERBERT}

As I know from personal experience, it is no simple matter to get access to police departments to conduct ethnographic research. When I was a $\mathrm{PhD}$ student in geography at the University of California, Los Angeles, I sought to understand the micro-geopolitics of policing, a project that required extensive observations. Were it not for the intervention of Willie Williams, then a brand new chief in the Los Angeles Police Department, my request for access would have been denied; all of the assistant chiefs, holdovers from the previous administration of Darryl Gates, argued against it.

Several years later, I encountered the same dynamic in Seattle. Denied initially by an assistant chief, I succeeded in gaining access only after appealing that decision to the chief. I cannot know for certain why my requests met opposition. In each case, I was asked by the police, "What is in this for us?" They indicated to me that the presence of researchers can be disruptive to the organization; it takes time and energy away from other, more pressing tasks. Given this, they wondered, what would I give back to the organization that would merit their efforts?

As understandable as this question might seem, I am unconvinced it was the real reason for their reluctance to grant my request. The more likely culprit, I speculated, was their concern that I would use any information I might gather to embarrass their department. Evidence for this hypothesis emerged in my negotiations with the LAPD about just where I would do my observations and for how long. At the conclusion of these discussions, I was asked to sign an agreement, in which I promised to publish nothing from my observations other than my $\mathrm{PhD}$ dissertation.

I eventually found a route around this obstacle, such that my dissertation research was published in both academic journals and in a monograph (Herbert 1997). Whether either this work or the book that emerged from the Seattle observations (Herbert 2006) was worth whatever costs were born by those two departments is not for me to judge. However, I am convinced, along with Anita Waters, that it is vitally important for the police to regularly open themselves up to academic researchers. I say this as not only a selfinterested police scholar, but as a citizen. As Waters accurately notes, "The tensions inherent in the relationship between police agencies and the general public push bureaucracies toward greater secrecy and simultaneously make 
transparency about police behavior even more valuable to democratic societies. Cadres of student ethnographers make at least a modest contribution toward that end."

Waters' essay makes obvious the myriad educational benefits that accrue to students who do extensive ethnographic work. They learn to observe, question, reconsider previous assumptions, analyze, and write. They get to practice, in essence, all of the skills intrinsic to a liberal arts education. Yet, as her observation about transparency makes clear, they get more than this they get an eyeful of state power in its most basic, everyday incarnations.

This is invaluable, both as a teaching tool and as an education in citizenship. To ask students to reckon with the discretionary authority of the police is a terrific vehicle for practicing the arts of analysis we want students to develop. But it also requires them to consider why these state practices are conducted in this particular way. How do coercive state agents come to possess such discretion? Why do they exercise their discretion as they do? Why does police practice vary from one municipality to another, from one neighborhood to another? What does it say about a state that licenses such variability in power's expression?

For this reason, I think Waters actually undersells the "research goal" she explicates for her class. She describes this goal as the quest "to understand the working lives of police officers from their own point of view." I am certain that this is the basal goal of the students' work, but her remarks indicate that there are larger projects under pursuit. Like all good ethnographers - indeed, like all good social analysts - Waters' students quickly stretch to broader questions about the social, political, and spatial organization of policing, and the congruence - or lack thereof - between what they are observing and what they hope to be true of democratic societies.

This is remarkably healthy for the students. And, even if they do not recognize it, it is healthy for the police, as well. They are, after all, a public institution, who must avail themselves to citizen observers, and who must become accustomed to explaining their actions to those observers. In my experience, few officers shy from an opportunity to describe their practices to an interested observer. And, even if they dislike any form of public criticism, the police can benefit from hearing a more dispassionate analysis of their activities, whether it comes from tenured academics like myself or newlyminted ethnographers like Waters' students.

In short, everyone benefits from the exchange. Here's hoping, then, that Waters' class persists for a long time, and that it is emulated widely, despite whatever opposition police departments might construct.

\section{References}

Herbert, Steve (1997) Policing Space: Territoriality and the Los Angeles Police Department. Minneapolis: University of Minnesota Press. 
Herbert, Steve (2006) Citizens, Cops, and Power: Recognizing the

Limits of Community. Chicago: University of Chicago Press

Steve Herbert

Department of Geography/Law, Societies and Justice Program

Box 353550, University of Washington

Seattle WA 98195-3550,

Email:skherb@u.washington.edu

\section{Making Trouble with the Police: Alternatives to Riding Along}

\section{ANTONIUS C.G.M. ROBBEN}

In the Spring of 1974, I set out on my bicycle to make a traffic violation in the center of Amsterdam. A young assistant professor at the University of Amsterdam had given us second-year sociology students the assignment to get arrested by the police, and write a paper about the experience. This ethnomethodological exercise in his research methods course was intended to make us discover the background of common understandings of everyday life by starting "with familiar scenes and ask what can be done to make trouble" (Garfinkel 1967:37).

Other Dutch social scientists were equally influenced by Garfinkel's staged research strategy. The anthropologists Bovenkerk and Luning carried out a natural experiment in 1978 to prove racism among the Dutch police after newspapers had reported that black Surinamese males riding in fancy American cars were frequently stopped, simply on the suspicion of being pimps or drug dealers. Two research assistants, one Surinamese Creole with a conspicuous Afro hairdo and one Caucasian, dark blond Dutchman, were asked to drive each a Chevrolet Malibu around the Netherlands. Both men were in their 30s, impeccably dressed, and each accompanied by a smartly dressed white Dutch blonde who might either be identified as a hooker or a successful businesswoman. The two couples drove around the four largest Dutch cities, and visited its red light districts, over the length of one weekend. A racially mixed panel of policemen and government employees predicted that the black driver would be stopped more often, and experience a harsher treatment from police, than the white driver. The surprising outcome was that 
the two research assistants were noticed by police dozens of times during their trips but were never pulled over. The researchers suggested that the reports about racial discrimination against male Surinamese drivers seemed to be overdrawn and based on the negative stereotyping of policemen (Bovenkerk and Luning 1979).

Aside from the ethical concerns of these field experiments, it is clear that covert or unobtrusive and overt or obtrusive research methods may yield quite different research outcomes. The ten students reporting back to Anita Waters had certainly a valuable research experience that changed their negative attitudes to a more benign view towards the police, as happened to the Dutch researchers mentioned above. Waters is to be lauded for designing such excellent exercise for her students. Still, I wonder how student opinions would have changed if their participant observation in patrol cars, next to the bibliographical survey of police ethnographies, had been complemented with methods examining the receiving end of law enforcement at the research setting. Students might have undertaken a methodological triangulation with the analysis of local newspapers, court cases against officers, and by interviews with students who had been in touch with the law. The ride-alongs gave the students a one-dimensional view of police officers as well of their interaction with superiors, colleagues, suspects, and bystanders. Triangulation teaches students that each method reveals only a portion of the social reality, that the same event yields different interpretations and meanings, and that researchers are implicated in the production of their findings.

Waters mentions that it is becoming harder to receive permission to accompany policemen on the beat because of security and liability concerns, a fear of negative outcomes, and an overall tendency towards secrecy. How to deal with this obstruction to gathering research data in the public domain? Natural experiments of the kinds described above are not recommended for students in these times of zero tolerance, heightened surveillance, and greater powers given to the police due to the global war on terror. The need for alternative unobtrusive research methods is thus increasing, and students might compensate for the inability to carry out participant observation by listening in on police radios, tagging along with reporters while using small cameras themselves to document police conduct, attending police courts, and interviewing retired police officers.

And what about my own research experience with the law in 1974? After cycling towards Amsterdam's city center, I finally spotted my research object: two policemen were standing near the entrance of the Nederlandsche Bank, Holland's central bank. I waited for the traffic light to turn red, and then cycled through it. There was no reaction from our two law enforcers. I turned my bike around, waited again for the light to turn red, and resumed my efforts at being detained by cruising slowly across the intersection while looking ostensibly at the two officers. They glanced at me, and just shook their heads. Later that day I asked my teacher if I could change my topic. Inspired by Erving Goffman, I finally wrote a paper about the behavior of visitors at a photo exhibit by Dianne Arbus at the Van Gogh Museum. 


\section{References}

Bovenkerk, Frank and Margreet Luning (1979) "Surinamers en grote auto's: Een 'levensecht experiment' om rassendiscriminatie op te sporen [Surinamese and big cars: A 'real-life experiment' to detect racial discrimination]." Intermediair 15(21):59-63.

Garfinkel, Harold (1967) Studies in Ethnomethodology. Englewood Cliffs, NJ: Prentice-Hall.

Antonius C.G.M. Robben

Dept. of Anthropology, Utrecht University

Heidelberglaan 2, 3584 CS Utrecht, Netherlands

Email:T.Robben@uu.nl

\section{Forum Reply}

\section{ANITA WATERS}

Steve Herbert, Antonius Robbin, and Chris Giacomantonio's insights about observing police practice first hand and at close range demonstrate conclusively that these methods yield important and otherwise unknowable data about the ways the state polices its subjects in modern societies. Steve Herbert's work on the way that officers use a "discourse of evil" to moralize about their work could only have been studied ethnographically. Chris Giacomantonio's work reminds us that despite the seeming uniformity of models of police practice, the high levels of discretion exercised on the beat result in divergent practices that are worthy of scrutiny. He demonstrates the value of ethnographic methods in revealing these divergences in different local sociopolitical contexts. Antonius Robbin suggests some ways that students could view police practice ethnographically from quite different standpoints that would deepen their understanding of state power and civilian liberties. He also recalls the infamous ethnomethodological experiments of the 1970s, which unfortunately are incongruent with contemporary securityconscious, hyper-litigious times.

I want to commend the Journal of Legal Anthropology for a Forum which brings these reflections together. One subject that deserves further comment is the question of access. Steve Herbert's response reminds me how 
fortunate I have been in obtaining permission for my students to ride-along with officers; departments fearful of negative publicity and disruption of routines are asking "What's in it for us?"

The departments to which my students have had access answer that question in several ways. First, they want to open access to potential recruits. Perhaps for this reason, it is easier to gain access for undergraduate students than for professional social scientists. Second, they use the ride-alongs to foster positive community relations, especially in a small college town where most police-student interactions are unpleasant ones. Our classroom discussion of the interactions that students have had with local officers before their fieldwork begins is, by the way, an admittedly unsystematic step toward the triangulation that Robbin recommends.

Ride-alongs offer police the opportunity to promulgate their perspective in the face of public criticism. This goal of image-management helps explain the continuing popularity among police departments - despite its proven ineffectualness - of the "Drug Abuse Resistance Education (DARE)" programs in the US that send officers into elementary schools for scripted programming aimed at convincing youngsters that police officers are their friends and should-be confidants.

The differential access to departments by student researchers is one of the variations that Chris Giacomantonio's work leads us to expect. Probably it is associated with variation in the connections that departments have with the communities that they serve. Some departments have greater tolerance than do others for their officers engaging in informal interactions with friends and family while on the job. These departments use the formal ride-along policies to regulate these interactions. For one department that my students study, the ride-along policy limited the number of times per year any one person could ride along; we learned that this was to prevent officers from routinely inviting spouses and friends from spending time with them while they were working.

When the police steadfastly refuse access, some of the settings that Antonius Robbin suggests, especially courtrooms, might offer greater visibility. While my students' research goal ("to understand the working lives of police officers from their own perspective"), which Herbert correctly points out is an undersell, might help gain access to first hand observations of police, broader insights into the social realities of law enforcement and state control are reachable through multiple methods, and are absolutely worth the effort.

\section{Anita Waters}

Department of Sociology/Anthropology

Denison University, Granville, Ohio 43023 USA

Email:waters@denison.edu 